\title{
DETERMINANTS OF CEE GOVERNMENT BOND SPREADS AND CONTAGION BETWEEN 2001-2014*
}

\author{
Kristóf GYÓDI \\ (Received: 9 March 2016; 14 November 2016; \\ accepted: 11 January 2017)
}

This paper analyses the pricing of sovereign risk and contagion during the crises in the Central and Eastern European countries. Panel data are used to estimate the determinants of government bond spreads in three different time periods: before the crisis, during the global financial crisis, and during the European debt crisis. The econometric model includes interactions between the explanatory variables and the crisis dummies. This specification enables the coefficients to change during the crises. The empirical analysis confirms a statistically significant relationship between sovereign risk and macroeconomic fundamental variables. Additionally, the results suggest an increase in the importance of macroeconomic fundamentals during the financial crisis. The analysis also supports that sovereign credit ratings and exchange rate risk have a significant impact on government bond spreads.

Keywords: government bond spreads, sovereign risk, sovereign credit rating, contagion, Central and Eastern European countries

JEL classification indices: E44, F30, G15, C23, H63

* The author wishes to thank Dr. Michał Brzozowski for his guidance, help, and comments, which were essential for this paper. The author would like to also express his gratitude to Prof. Dr. Hab. Jan Jakub Michałek and Dr. Jan Hagemejer for their suggestions and recommendations.

Kristóf Gyódi, PhD candidate at the Faculty of Economic Sciences, University of Warsaw. E-mail: kgyodi@coin.wne.uw.edu.pl 


\section{INTRODUCTION}

The economic literature suggests that the cost of government borrowing is determined by macroeconomic fundamentals, especially by fiscal accounts (Mundell 1963). However, the relationship between the fundamental conditions and sovereign risk may change during periods of high volatility on financial markets (Attinasi et al. 2009; Barrios et al. 2009; Von Hagen et al. 2011). Government bond yields demonstrated an increased variation across countries during the global financial crisis. Contagion, defined as a change in the way fundamentals or other factors are priced during a crisis, had a significant impact on sovereign risk not only in the euro zone, but globally as well (Giordano et al. 2013; Ludwig 2014). While there is a wide empirical literature on the drivers of sovereign risk in the euro zone, analyses focusing on the Central and Eastern European (CEE) countries that joined the European Union are relatively scarce.

The aim of this analysis is to verify the determinants of government bond spreads denominated in local currencies in 9 CEE countries. The econometric model, based on the work of Beirne - Fratzscher (2013), includes interactions between the explanatory variables and crisis dummies. This specification allows the coefficients to change two times in the examined period: during the global financial crisis and during the European debt crisis. Therefore, the changes in the pricing of sovereign risk can be analysed in the different phases of the crisis. The role of exchange rate risk is examined as well, following the recent literature on emerging economies (e.g. Gadanecz et al. 2014).

Additionally, our econometric model is extended with dummy variables of sovereign credit ratings, in order to estimate the impact of every credit rating individually. Sovereign credit ratings are constructed by rating agencies based on various economic, social, and political determinants. According to the empirical literature, the economic determinants of ratings include inflation, external debt, default history, per capita income, and level of openness (Cantor - Packer 1996; Canuto et al. 2004). Ratings are important signals for investors, and seem to have an additional effect on spreads beyond the country macroeconomic fundamental variables, especially in the case of investment-status ratings (Jaramillo - Tejada 2011; Cavallo et al. 2013).

In this paper, we follow the approach of Beirne - Fratzscher (2013) to define contagion as 'the change in the way countries' own fundamentals or regional risk are priced during a particular period, i.e. a change in the reaction of financial markets either in response to observable factors, such as changes in sovereign risk among neighbouring countries, or due to unobservables, such as herding behaviour of market participants" (op. cit.: 65). Wake-up call contagion is a change in the pricing of certain macroeconomic fundamentals during the crisis. Regional 
contagion is a change in the pricing of regional risk. Pure contagion means herding behaviour or panic among investors. Some authors differentiate shift-contagion as well, which means greater sensitivity to a common factor such as global risk aversion. This is a specific case of wake-up call contagion (Giordano et al. 2013).

The research hypotheses are the following: (i) The relationship between the macroeconomic fundamental variables and government bond spreads changed during the crises. (ii) The impact of macroeconomic fundamentals increased during the global financial crisis, while the effect of regional risk strengthened during the European debt crisis. (iii) Sovereign credit ratings are significant drivers of government bond spreads.

During the financial crisis, investors focused more on cross-country differences and changes in macroeconomic fundamentals, which indicates wake-up call contagion. In the period of the debt crisis, however, investors no longer differentiated strongly between the countries of the region. Government bond spreads were mainly driven by the average regional level of spreads, which suggests regional contagion. A significant impact of sovereign credit ratings implies that ratings contain additional information for investors. Therefore, sovereign credit ratings have an impact on government bond spreads on their own that is independent from macroeconomic fundamentals.

\section{GOVERNMENT BOND SPREADS IN THE CEE COUNTRIES}

The analysis focuses on the following CEE countries: Bulgaria, the Czech Republic, Hungary, Latvia, Lithuania, Poland, Romania, Slovakia, and Slovenia. Croatia and Estonia, the remaining EU members of the region, are omitted from the analysis due to insufficient data. Despite the similar geographical location and economic history, the analysed countries form a heterogeneous group. This is illustrated by the huge differences in the per capita income adjusted for purchasing power parity, which varied between 30 per cent (Bulgaria) and 80 per cent (Slovenia) of the EU-15 average in the period 2006-2008 (Staehr 2010). Furthermore, these countries use different exchange rate regimes. A few of them chose deeper integration by joining the European Monetary Union (EMU): Slovenia adopted the euro in 2007, Slovakia in 2009, Latvia in 2014 and Lithuania in 2015. This means that these countries had a fixed exchange rate for a large share of the examined time period. Bulgaria has a currency board arrangement, while Poland, Hungary, the Czech Republic, and Romania have floating exchange rates.

The convergence of the CEE countries towards the EU-15 had been relatively fast in the period 2004-2007. These countries attracted one-third of all private 
capital inflows to emerging markets between 2002 and 2007 (Kattel 2010). Foreign investments allowed the CEE countries to consume and borrow more during the pre-crisis period, thus foreign investments contributed to the fast economic growth and to the large current account deficits as well. Even though direct investments have been financing a large share of the current account deficits, the external financing needs of the region remained high (Vamvakidis 2009).

The global financial crisis, however, abruptly ended this period of prosperity. The sudden fall of external demand and the evaporation of foreign funds severely struck the CEE countries. The recovery was rather slow due to the low growth in the euro zone, higher risk aversion, and decreased foreign investments.

Figure 1 and Figure 2 present bond yield spreads at secondary markets with 10 -year maturity in the CEE countries over Germany. Three different periods can be differentiated in the figures: the pre-crisis period (January 2001-August 2008), the global financial crisis (September 2008-March 2010), and the European sovereign debt crisis (April 2010-July 2014).

In the pre-crisis period, the region seemed to be divided into two groups of countries: Bulgaria, the Czech Republic, Slovenia, Slovakia, and the Baltic countries had negligible spreads over German interest rates, while investors demanded higher interest from Hungary, Poland, and Romania. The average standard deviation of bond yields across countries has been relatively low: 1.27 percentage points (pp). The variance of government bond yields across countries became

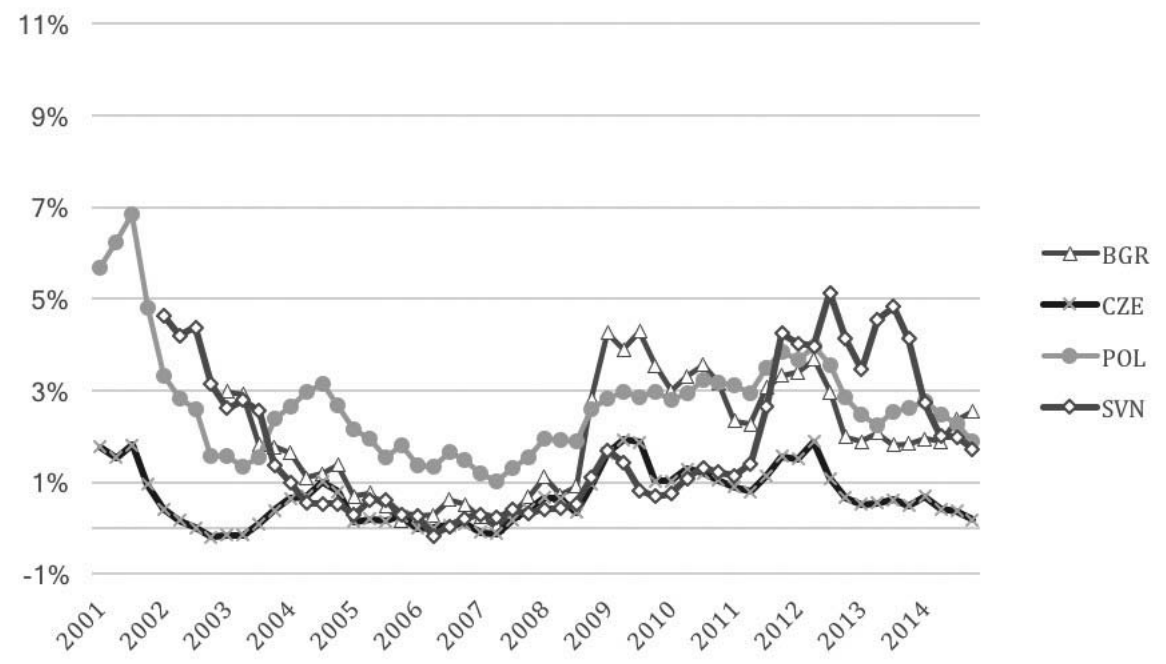

Fig 1. Annual government bond yield spreads over Germany in the period 2001-2014 Source: Own calculations based on data from Eurostat. 


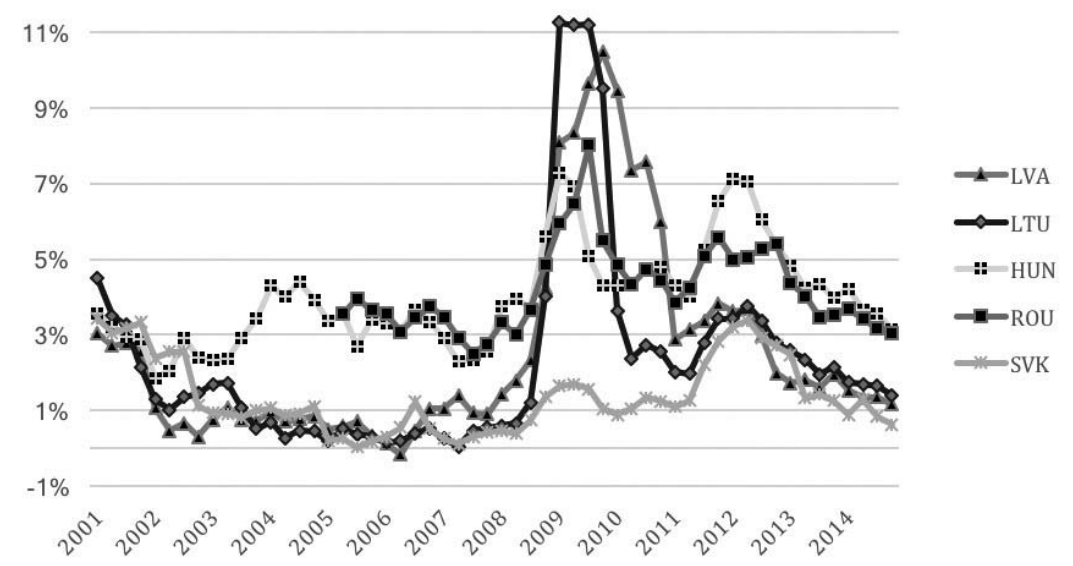

Fig 2. Annual government bond yield spreads over Germany in the period 2001-2014 Source: Own calculations based on data from Eurostat.

much greater following the collapse of Lehman Brothers, the average standard deviation increased to $3.15 \mathrm{pp}$. Bond yields rose sharply in the Baltic States (up to almost $15 \%$, more than $11 \mathrm{pp}$ above German yields), Hungary and Romania (up to $8 \%$ spreads). The rise in the cost of new debt caused severe liquidity problems in Hungary, Romania, and Latvia; these countries needed joint IMF/EU bailout programmes. Polish bond yields stagnated at around 6\% during the global financial crisis. Poland increased its credibility with a "flexible credit line" agreement with the IMF (Staehr 2010). Slovakia and Slovenia, the two CEE members of the euro zone, along with the Czech Republic, managed to keep bond yields relatively low, around the 5\% level ( $2 \%$ higher than German interest rates).

At the beginning of 2010, bond spreads began to decrease in the region, and by the end of 2011, they had returned to the pre-crisis level. During this period, the European debt crisis developed, with high bond spreads in the EMU peripheral countries. This suggests that the initial phase of the euro zone crisis did not have a strong impact on the sovereign risk of the CEE region. Bond spreads increased once more at the beginning of 2012. This increase may have been caused by the uncertainty regarding the future of the EMU. However, spreads have been on a decreasing trend since 2013, primarily due to the more active role of the European Central Bank in stabilising the economy. The measures introduced by ECB President Mario Draghi included government bond purchasing programmes and quantitative easing programmes (Claeys et al. 2016). The average standard deviation of bond yields across CEE countries decreased to a similar level as in the pre-crisis period, to $1.45 \mathrm{pp}$. 


\section{REVIEW OF THE LITERATURE}

There is a wide empirical literature on the determinants of government bond yields in advanced and emerging economies. Most of the authors analyse panel data and focus on fiscal variables. Poghosyan (2014) analyses the long-term and short-term drivers of interest rates using a panel of 22 advanced countries and panel cointegration techniques. Gruber - Kamin (2010), Laubach (2009), and Ardagna et al. (2007) find robust and significant impact of debt and deficit on bond yields in advanced economies. Baldacci - Kumar (2010) examine a wide panel of 33 advanced and emerging economies and find a significant and non-linear relationship between long-term interest rates, debt, and deficit. Jaramillo - Weber (2012) show that during volatile periods, the impact of fiscal variables on sovereign bond spreads increases in emerging economies. Miyajima et al. (2015) find that during high market volatility, global factors can overwhelm domestic fundamentals in emerging markets. Alexopoulou et al. (2009) conclude that external debt, fiscal balance, inflation rate, trade openness, exchange rate, and short-term interest rate spreads are the most important long-run drivers of bond spreads in 8 new EU countries. Gadanecz et al. (2014) show that exchange rate risk is a significant determinant of local government bond yields in emerging economies, finding a significant and robust positive impact of exchange rate volatility. Iara - Wolff (2014) present the significant impact of national fiscal governance and numerical fiscal rules on government bond spreads in the euro area, controlling for standard fiscal variables.

This paper is based on the work of Beirne - Fratzscher (2013), who analyse the determinants of sovereign risk and the presence of contagion in the period 2000-2011 in a panel of 10 euro zone economies, 7 advanced countries outside the euro zone and 14 emerging economies. The benchmark model includes five macroeconomic fundamental variables: debt to GDP, fiscal balance to GDP, real GDP growth, the current account balance, and the global market volatility, proxied by the VIX index (the CBOE Volatility Index is a widely used measure for expected stock market volatility). The authors find that sovereign spreads were driven by public debt, GDP growth, and the regional price of sovereign risk before the crisis. The emerging economies were more sensitive to public debt and fiscal balance than the advanced economies. During the crisis, spreads became much more sensitive to fundamentals in the euro zone, especially in the peripheral countries, while the relationship stayed almost the same in the case of the emerging economies. This result suggests the presence of wake-up call contagion in the euro zone. An important finding is that regional contagion has been unimportant during the crisis: cross-country transmission of sovereign risk decreased, especially in the euro zone. Giordano et al. (2013) focus on the euro area and con- 
clude that the sharp increase in spreads was caused by wake-up call contagion, but no pure contagion took place. Gómez-Puig - Sosvilla-Rivero (2014) also confirm a wake-up call contagion in the euro zone and find evidence in favour of regional contagion as well.

Numerous papers focus on changes in cross-country linkages, with the usage of different time-series methodologies (VAR, GARCH, Engel and Granger twostep method, etc.). The authors confirm time-variant spillover effects in the euro zone (Antonakakis et al. 2013; Leschinski - Bertram 2013; Gómez-Puig et al. 2014). Relevant to the CEE countries, Claeys et al. (2014) find that the countryspecific effects explain a larger share of bond spreads variation in Poland, Hungary, and the Czech Republic than in the euro zone countries.

\section{THE METHODOLOGY}

The theoretical framework of our model is based on the work of Beirne-Fratzscher (2013). The basis of the econometric model is the definition of sovereign risk. Sovereign risk (the credit risk of operations involving credit for sovereign states) is determined by credit risk, liquidity risk and risk appetite:

$$
r=(1-P(X))(1-\mu)+\Omega+\phi
$$

where $r$ is the government bond yield of a given country relative to a risk-free asset (spread), $(1-\mathrm{P}(X))$ is the probability of default, $(1-\mu)$ is the loss in case of default, $\Omega$ is the risk premium, and $\phi$ is the liquidity premium.

The government bond spread is the difference between the yield to maturity of a given country's government bond and the respective yield to maturity of another country's government bond. The government bond used as a reference is usually nearly risk-free, e.g. the German government bond (Ebner 2009).

The econometric model used to verify the research hypotheses is a country fixed-effects panel data model. Country fixed-effects allow controlling for time-invariant unobserved heterogeneity. Unobserved heterogeneity may include factors affecting sovereign risk such as institutions, the level of democracy, history, etc.

The simplest form of the model is the following:

$$
r_{i, t}=\alpha_{0}+\alpha_{i}+\beta_{k} X_{k, i, t}+\gamma_{1} S_{j, i, t}+\varepsilon_{i, t}
$$

where $r_{i, t}$ is the government bond spread, $\alpha_{0}$ is the common intercept, $\alpha_{i}$ is the country fixed-effect, $X_{k, i, t}$ is a vector with the determinants of the government bond yields, $S_{j, i, t}$ is the regional price of sovereign risk, and $\varepsilon_{i, t}$ is the error term. 
$S_{j, i, t}$ is the unweighted average of the CEE government bond spreads in time $t$, excluding country $i$ itself. Therefore, the coefficient $\gamma_{1}$ measures the impact of the regional sovereign risk on the sovereign risk of the individual countries.

This basic model is modified in order to allow a shift in the coefficients over time. The extended model can be used to identify contagion-effects. The model takes the following form:

$$
\begin{aligned}
& r_{i, t}=\alpha_{0}+\alpha_{i}+\beta_{k} X_{k, i, t}+\gamma_{1} S_{j, i, t}+\left(\beta_{k}^{\prime} X_{k, i, t}+\gamma_{1}^{\prime} S_{j, t}\right) D_{t}^{F}+ \\
& \left(\beta_{k}^{\prime \prime} X_{k, i, t}+\gamma_{1}^{\prime \prime} S_{j, i, t}\right) D_{t}^{D}+\varepsilon_{i, t},
\end{aligned}
$$

where $D_{t}^{\mathrm{F}}$ is a dummy for the global financial crisis, while $D_{t}^{\mathrm{D}}$ is a dummy for the European debt crisis. This specification allows the coefficients to change two times in the examined period. The dummy for the global financial crisis takes the value of 1 between October 2008 and March 2010. The standard starting date of the global financial crisis is September 15, 2008, when the Lehman Brothers went bankrupt. April 2010 is chosen as the starting date for the debt crisis, as in the analysis of Suh (2015). Greece requested a loan from the EU and IMF in April 2010, which was followed by S\&P's downgrade of the Greek sovereign debt to $\mathrm{BB}+$ (which is already in the non-investment or "junk bond" category). An alternative starting date is October 2009, when the Greek government revised its budget deficit numbers. Giordano et al. (2013) and Gómez-Puig et al. (2014) use this date among others. However, the later starting date allows a better assessment of the true impact of the debt crisis in the CEE region, as the euro zone sovereign bond spreads began to increase sharply only from April 2010 (Lane 2012). Therefore, $D_{t}^{\text {D }}$ takes the value of 1 from April 2010. The fiscal situation of Greece is still not stable; there is no established end date for the debt crisis. The examined time period ends with July 2014 in this analysis.

With this framework, the drivers of sovereign risk can be assessed in three different periods. During the pre-crisis period (January 2001-September 2008), the relationship between bond yields and macroeconomic fundamentals is measured by $\beta_{k}$. During the global financial crisis (October 2008-March 2010), the impact is given by $\beta_{k}+\beta_{k}{ }^{\prime}$. During the debt crisis (April 2010-July 2014), the corresponding value is $\beta_{k}+\beta_{k}^{\prime \prime}$. A statistically significant change in the coefficients means wake-up call contagion. The impact of regional risk can be measured the same way by $\gamma_{1}, \gamma_{1}^{\prime}$ and $\gamma_{1}^{\prime \prime}$. A statistically significant change in the coefficients means regional contagion. The next section describes the details of the data set. 


\section{THE DATA SET}

The dependent variable of the model is the government bond spread, derived as the difference between the local currency government bond yields of CEE countries and the corresponding German bond yield. The data originate from the EMU convergence criterion series that present interest rates for long-term government bonds, denominated in national currencies. The time series cover the period from January 2001 to July 2014. Countries with shorter periods of observations are the following: for Bulgaria, data is available from January 2003, for Romania from April 2005, and for Slovenia from March 2002. The spread is interpreted in percentages per annum multiplied by 100 .

The following macroeconomic variables are used.

GDP growth: cyclical developments in output growth affect long-term interest rates in the short-run. While potential output growth has a positive effect on real bond yields (Poghosyan 2014), short-run GDP growth has a negative impact on bond yields. GDP growth is associated with a decrease in sovereign risk, as the country's taxing capacity increases.

Real short-term interest rates: a tighter monetary policy should lead to higher short-term and long-term interest rates. Money market rates are used to control for monetary policy in empirical works.

Current account balance: it reveals the exposure of a country to the rest of the world. A current account deficit is a sign that the country is spending abroad more than its earnings from foreign transactions, thus the country is becoming a net debtor towards the rest of the world. The expected impact is thus negative.

Government debt: public debt can affect bond yields through two main channels: the crowding out of private investments by fiscal expansion (Elmendorf et al. 1999) and by increasing the risk premium. Additionally, higher government debt can create uncertainty for the monetary policy, as central banks have a greater incentive to monetise government debt.

Primary balance ratio: the primary government deficit ratio reflects the cyclical fiscal policy developments. A negative relationship is expected between long-term interest rates and deficit, as an improvement in the balance ratio lowers sovereign risk.

Besides the standard control variables suggested by the literature, the role of exchange rate risk is examined as well. Exchange rate risk, which may be of high importance in the case of the emerging economies, is expected to have a positive impact on sovereign risk. Exchange rate risk may affect fiscal sustainability for several reasons. Firstly, unfavourable changes in the exchange rate create losses for foreign investors on their bond positions. Secondly, large currency mismatches of the banking or household sector balance sheets may pose a threat for the fi- 
nancial system. Exchange rate risk may also reduce foreign demand for domestic assets, thus reducing liquidity in financial markets (Gadanecz et al. 2014). These arguments imply that causality runs from exchange rate risk to sovereign risk. On the other hand, the direction of causality is not entirely clear. Foreign exchange rate markets are more liquid than sovereign debt markets, therefore investors often hedge their bond positions on the foreign exchange market. In this case, the higher volatility of the government bond market can affect exchange rates as well (Gadanecz et al. 2014). Exchange rate risk is controlled for with two variables: change in the exchange rate and exchange rate volatility. Change in the exchange rate measures the percentage change of average quarterly exchange rate against the euro. Exchange rate volatility is measured by the coefficient of variation. The coefficient of variation (standard deviation divided by the average) is calculated from daily exchange rates against the euro. The advantage of this measure over the simple standard deviation is that it solves the problem of different units that the different exchange rates present.

All variables are in quarterly frequency. The variables with a seasonal component are seasonally adjusted.

Furthermore, three other determinants are included in the model: global risk, sovereign credit ratings, and fiscal rules. VIX index: the CBOE Volatility Index is widely used to control for the common global risk factor. The index, based on the S\&P 500 Index, measures stock market volatility. An increase of global risk should lead to an increase of government bond yields, especially in the case of emerging countries. Sovereign credit ratings: ratings are added to the model to test the hypothesis that they are significant drivers of government bond yields. The data set includes the long-term local currency sovereign ratings by Fitch. First, the ratings were transformed into numeric values from 1 (rating D) to 24 (rating AAA). In practice, the ratings varied between 10 (rating B) and 22 (rating AA) in the examined period. Second, the ratings have been transformed into dummy variables, as in Jaramillo - Tejada (2011), in order to assess the impact of every rating separately. Fiscal rules: numerical fiscal rules decrease spreads by reducing the probability of default. Similarly to Iara - Wolff (2014), the fiscal rule index is used in the empirical analysis. ${ }^{1}$ The index is based on five dimensions, describing fiscal rules at the local, sub-national, or national level: the statutory base of the rule, room for revising objectives, mechanisms of monitoring compliance with and enforcement of the rule, the existence of enforcement mechanisms, and media visibility of the rule. A comprehensive time-varying fiscal rule index for each EU member state was constructed by summing up all fiscal rule strength

1 The dataset is accessible at http://ec.europa.eu/economy_finance/db_indicators/ fiscal_governance/index_en.htm. 
indices in force in the respective Member State weighted by the coverage of general government finances of the respective rule (Iara - Wolff 2014). As the index is updated only on an annual basis, it has been transformed into quarterly frequency (the annual value was assigned to the quarterly values).

The source of the data is the Eurostat for most of the variables. The values of the VIX index are provided by the Chicago Board Options Exchange (CBOE); data on sovereign ratings originate from Fitch Ratings, central banks and ministries of finance, while the fiscal rule index is obtained from the European Commission's Directorate-General for Economic and Financial Affairs.

\section{THE EMPIRICAL ANALYSIS}

The regressions are estimated using the fixed-effects estimation method. The Hausman test showed systematic differences between the random-effects and fixed-effects estimators, therefore the consistent fixed-effects estimator is used (Table 1). In order to estimate the country fixed-effects, the least square dummy variable estimator is implemented.

The VIF test (variance inflation factor) was carried out to check for multicollinearity. If the explanatory variables are strongly correlated to each other, the standard errors may be biased. The results suggest that there are no high correlations among the variables, including the dummy variables for credit ratings: the average VIF value is below 3 . There are different views on which VIF level poses a problem; usually a value above 10 needs attention.

The results of the estimations are presented in Table 1. For the pre-crisis period $\beta_{k}$, for the financial crisis period $\beta_{k}{ }^{\prime}$, while for the debt crisis period $\beta_{k}{ }^{\prime \prime}$ is reported. This means that the coefficients for the financial crisis and the debt crisis period show the relative change to the pre-crisis period: when both $\beta_{k}$ and $\beta_{k}{ }^{\prime}$, or $\beta_{k}$ and $\beta_{k}$ " are significant, the sum $\beta_{k}+\beta_{k}^{\prime}$ gives the impact of the variable during the financial crisis period, and $\beta_{k}+\beta_{k}$ " during the debt crisis period. The same applies for the coefficients of regional contagion $\gamma_{1}, \gamma_{1}^{\prime}$ and $\gamma_{1}^{\prime \prime}$.

\subsection{Regression without credit ratings}

Firstly, the model specification without credit ratings is analysed. The results confirm that macroeconomic fundamentals are the main drivers of CEE government bond spreads: GDP growth, government debt, current account balance and money market interest rates are statistically significant determinants. Following a percentage point increase of the GDP growth, spreads decreased by around 6 
Table 1. Results of fixed-effects regressions

\begin{tabular}{lcc}
\hline VARIABLES & $\begin{array}{c}(\mathbf{1}) \\
\text { Spread }\end{array}$ & $\begin{array}{c}(\mathbf{2}) \\
\text { Spread }\end{array}$ \\
\hline Pre-crisis $\left(\beta_{k}, \gamma_{\mathrm{i}}\right)$ & & \\
Regional bond spreads & -0.012 & 0.113 \\
GDP growth & $-0.057^{* *}$ & -0.029 \\
VIX index & 0.007 & 0.001 \\
Money market interest rates & $0.301^{* * *}$ & $0.275^{* * *}$ \\
Primary balance to GDP & -0.046 & -0.030 \\
Current account balance to GDP & $0.0705^{* * *}$ & 0.023 \\
Government debt to GDP & $0.039^{* * *}$ & $0.032^{* * *}$ \\
Exchange rate change & -0.011 & 0.001 \\
Exchange rate volatility & 8.786 & 12.53 \\
Fiscal rules & -0.120 & -0.142 \\
Rating: BBplus & & $2.675^{* * *}$ \\
Rating: BBBminus & & $1.441^{*}$ \\
Rating: BBB & & $1.708^{* * *}$ \\
Rating: BBBplus & & $1.192^{* *}$ \\
Rating: Aminus & & $1.066^{* *}$ \\
Rating: A & & $0.861^{*}$ \\
Rating: Aplus & & 0.719 \\
Rating: AAminus & & 0.705 \\
\hline
\end{tabular}

Global Financial Crisis $\left(\beta_{k}{ }^{\prime}, \gamma_{1}{ }^{\prime}\right)$
Regional bond spreads
GDP growth
VIX index
Money market interest rates
Primary balance to GDP
Current account balance to GDP
Government debt to GDP
Exchange rate change
Exchange rate volatility
Fiscal rules
Rating: BBBminus
Rating: BBB
Rating: BBBplus
Rating: Aminus
Rating: A
Rating: Aplus
Rating: AAminus
Rating: AA

$\begin{array}{cc}-0.542^{* * *} & -0.677^{* * *} \\ -0.312^{* * *} & -0.288^{* * *} \\ 0.022 & 0.017 \\ -0.150^{* *} & -0.374^{* * *} \\ -0.156^{* * *} & 0.019 \\ -0.094^{* *} & -0.082^{*} \\ 0.026^{* *} & -0.019 \\ 0.031 & 0.014 \\ -46.35^{* *} & -25.78 \\ 0.559^{*} & 0.905^{*} \\ & 6.586^{* * *} \\ & 2.695^{* *} \\ & 6.718^{* * *} \\ & 8.102^{* * *} \\ & 3.271^{*} \\ & 3.741^{* *} \\ & 3.991^{* *} \\ & 1.624\end{array}$


Table 1. continued

\begin{tabular}{|c|c|c|}
\hline VARIABLES & $\begin{array}{c}\mathbf{( 1 )} \\
\text { Spread } \\
\end{array}$ & $\begin{array}{c}(2) \\
\text { Spread }\end{array}$ \\
\hline \multicolumn{3}{|l|}{ European Debt Crisis $\left(\beta_{k}{ }^{\prime \prime}, \gamma_{1}{ }^{\prime}\right)$} \\
\hline Regional bond spreads & 0.223 & $0.553 * * *$ \\
\hline GDP growth & $-0.106^{* *}$ & -0.025 \\
\hline VIX index & 0.035 & $0.051 * * *$ \\
\hline Money market interest rates & 0.074 & -0.036 \\
\hline Primary balance to GDP & 0.02 & 0.003 \\
\hline Current account balance to GDP & 0.039 & 0.055 \\
\hline Government debt to GDP & 0.003 & 0.003 \\
\hline Exchange rate change & -0.014 & -0.022 \\
\hline Exchange rate volatility & -21.93 & $-25.37 *$ \\
\hline Fiscal rules & -0.002 & 0.212 \\
\hline Rating: BBBminus & & -0.344 \\
\hline Rating: BBB & & $-1.305^{* *}$ \\
\hline Rating: BBBplus & & $-1.698 * *$ \\
\hline Rating: Aminus & & $-1.281^{*}$ \\
\hline Rating: A & & $-1.332 *$ \\
\hline Rating: Aplus & & $-1.336^{*}$ \\
\hline Rating: AAminus & & $-1.877 * *$ \\
\hline Rating: AA & & $-2.580 * * *$ \\
\hline Bulgaria & $2.309 * * *$ & 0.766 \\
\hline Czech Republic & -0.0233 & -0.02 \\
\hline Latvia & $2.201 * * *$ & $1.247 * *$ \\
\hline Lithuania & $1.875 * * *$ & $0.939 *$ \\
\hline Poland & 0.163 & 0.351 \\
\hline Romania & $2.792 * * *$ & $1.725 * * *$ \\
\hline Slovenia & 0.343 & $1.454 * * *$ \\
\hline Slovakia & 0.221 & -0.069 \\
\hline Constant & $-1.600 * *$ & $-2.370 * * *$ \\
\hline R-squared & 0.829 & 0.91 \\
\hline Observations & 418 & 418 \\
\hline
\end{tabular}

Source: Own calculations.

Note: Standard errors in parentheses ${ }^{* * *} \mathrm{p}<0.01,{ }^{* *} \mathrm{p}<0.05,{ }^{*} \mathrm{p}<0.1$. 
basis points in the pre-crisis period. A $1 \mathrm{pp}$ increase of government debt increased spreads by 4 basis points, although the government deficit was not significant. The current account balance had a positive coefficient; however, the expected sign is negative, as a current account deficit contributes to the growth of external debt. On the other hand, the pre-crisis period has been characterised by increasing current account deficits and decreasing long-term interest rates in the CEE region (Giday 2013). This suggests that investors were not sensitive to the substantial current account deficits during the pre-crisis period.

The results also reveal that government bond spreads were not driven by regional risk during the pre-crisis period, as the average regional spreads were insignificant. This may imply that investors assessed the sovereign risk of CEE countries individually already before the financial crisis. The VIX index, variables on exchange rate volatility and currency depreciation, and fiscal rules were also insignificant.

During the financial crisis, the relationship between spreads and their determinants changed, which signals contagion. The impact of regional bond spreads became significant and highly negative, which is unusual, as it means that due to increasing regional risk, the spreads of the individual countries decreased. This may imply a strong divergence among the CEE bond yields. As it has been discussed earlier, euro zone members and Poland did not witness sudden increases in the bond yields during the financial crisis, unlike others, especially the Baltic States and Romania.

The impact of the macroeconomic variables significantly increased, which is a strong indicator for wake-up call contagion. The impact of economic growth jumped from 6 basis points to around $37(5.7+31.2)$ basis points, and the impact of the current account balance became negative: spreads decreased by 2.4 (7.059.4) basis points, following a $1 \mathrm{pp}$ improvement of the balance. Regarding fiscal variables, deficit became significant with almost 16 basis points impact, and the impact of government debt increased from 3.9 to 6.5 basis points. The effectiveness of monetary policy declined, as the impact of money market rates halved (from 30 basis points to 15 basis points).

The coefficient for the impact of exchange rate volatility was significant and strongly negative during the financial crisis. Following a unit increase in the coefficient of variation, bond spreads decreased by more than $46 \mathrm{pp}$. This is an interesting finding, as it suggests that the high variance of exchange rates helped to decrease sovereign risk in the CEE countries with free floating exchange rate regimes. During times of high volatility on the financial markets, exchange rates absorbed much of the external shock. Fiscal rules also became significant (at the $10 \%$ significance level), with a positive impact. As fiscal rules are revised only on an annual basis, this result should be interpreted in caution. 
During the debt crisis, the relationship between the macroeconomic fundamentals and sovereign risk returned to the levels observed in the pre-crisis period. The exception is GDP growth, which remained a strong factor in the pricing of sovereign risk, although with a lesser impact than during the financial crisis (16.3 basis points impact: $5.7+10.6$ ). The pricing of the other variables did not change relative to the pre-crisis periods.

The country fixed-effects control for the unobserved heterogeneity across countries. The impact of the fixed-effects are estimated relative to Hungary: they are significant and positive in the case of the Baltic countries, Romania and Bulgaria.

In sum, our results suggest that investors assessed the sovereign risk of CEE countries individually during the entire analysed time period, based on the differences in macroeconomic fundamentals. The results indicate wake-up call contagion during the financial crisis, as the increase of spreads during the global financial crisis was mainly driven by the decline in economic output, increasing budget deficits and debt. During the debt crisis, investors priced sovereign risk similarly as during the pre-crisis period. The results reveal no regional contagion during the crises. The analysis provides an interesting discovery concerning exchange rate risk: the countries with free-floating exchange rates benefited from the high volatility of their currencies during the crises. This is in line with the findings of Jahjah et al. (2012), who analyse the impact of exchange rate regimes on foreign currency denominated government bond yields in 42 emerging countries. The authors conclude that countries with free-floating exchange rate regimes have significantly lower spreads. The analysis does not support the important role of fiscal rules in pricing sovereign risk in CEE countries.

It is interesting to place the results in the context of the empirical literature. The estimated impact of macroeconomic variables is similar to the results of other authors. The impact of debt ( $4-6.5$ basis points following a $1 \mathrm{pp}$ increase) is in the range of the 2-7 basis points as reported by Baldacci - Kumar (2010) and Poghosyan (2014).

The estimated impact of deficit (16 basis points during the financial crisis) is similar to the results of others: e.g. Jaramillo - Weber (2012) report a 13-15 basis points increase for the period 2005-2011. The positive impact of the net current account in emerging economies is also observed by other authors, including Beirne - Fratzscher (2013) as well. The impact of GDP growth (6-37 basis points) seems reasonable too: e.g. Miyajima et al. (2015) report 27 basis points. 


\subsection{Regressions with credit rating data}

Next, the previous specification of the model is extended with sovereign credit ratings by Fitch Ratings. The results of the regressions are presented in the second column of Table 1.

The results show that sovereign credit ratings significantly affect government bond spreads, even after controlling for macroeconomic fundamentals. The estimated coefficients prove that better credit ratings are associated with lower spreads. The greatest effect is associated with a change between ratings BBBand $\mathrm{BB}+$, which means a downgrade into the "junk bond" (non-investment) category. Such downgrade is associated with a higher increase of spreads (1.2 pp increase) rather than with a change within the investment category. The measured coefficient for government debt is less relative to the basic estimation, while GDP growth and the current account balance are insignificant.

The coefficients for credit ratings were very high during the financial crisis, which reflects the significant increase of bond yields. Furthermore, as credit ratings change relatively rarely, their interaction with the crisis dummy $\left(\beta_{k} D_{t} F\right)$ captures part of the unexplained variance during the financial crisis.

The impact of money market rates turned negative: following a $1 \mathrm{pp}$ decrease of short-term interest rates, spreads increased by almost 10 basis points $(27.5-$ 37.4). This suggests the impairment of monetary transmission channels during the crisis in the CEE countries.

The impact of regional bond spreads is again significant and negative, similarly to the base regression. This suggests a strong divergence between the sovereign risk of the CEE countries, as the huge increase of spreads in the more crisis-struck countries (Baltic countries, Romania, and Hungary) may have diverted investors towards the more stabile economies of the region.

Regarding macroeconomic variables, GDP growth is a strong indicator for investors during the financial crisis in this specification of the model as well (28.8 basis points impact); however, the impact of fiscal variables did not change relative to the pre-crisis period (as the variables interacted with the crisis dummy are insignificant). However, the results show that investors paid additional attention to the current account balance ( 8 basis points impact). These results suggest that the wakeup call contagion was restricted to changes in the output and current account balance, while investors did not change the pricing of fiscal variables during the crisis.

The coefficients for credit ratings reflect the lower level of interest rates during the debt crisis. The impact of regional bond spreads became significant and positive (following a percentage point increase of regional spreads, individual spreads rose by 55 basis points). This signals that the region's sovereign risk started to influence the spreads of the individual countries, which was not the 
case before 2012. Investors may have begun to assess the sovereign risk of CEE countries viewing the whole region together, which means regional contagion.

The VIX index became statistically significant with a p-value of less than 5\%. This change suggests shift-contagion: bond yields became more sensitive to a common, external factor. This supports that CEE countries were affected primarily by the uncertainties and vulnerability of the euro zone, and not by macroeconomic shocks within the region. Furthermore, the higher exchange rate volatility is again associated with a negative impact on spreads.

In sum, the results suggest a weaker relationship between macroeconomic fundamentals and spreads, once sovereign ratings are controlled for. During the financial crisis, the impact of GDP growth intensified, which shows wake-up call contagion, although the pricing of fiscal variables did not change. There is additional evidence for the negative impact of exchange rate volatility during the debt crises. The results are robust for wake-up call contagion, while there is also some evidence for regional contagion during the debt crisis.

As robustness tests, two more specifications are verified. Firstly, the examined time period is shortened, therefore the debt crisis period is between April 2010 and December 2012. The main conclusions are unchanged: the pricing of sovereign risk returned to the pre-crisis relationships during the debt crisis, with mixed evidence on regional contagion.

The second robustness test examines the significantly negative impact of regional risk on spreads during the debt crisis. Four countries are left out from the panel: Lithuania, Latvia, Hungary, and Romania. The regressions on a restricted panel suggest that the impact of regional risk during the financial crisis did not change, thus the negative impact observed in the whole panel was indeed caused by the divergent trends of government bond yields in the less stable countries of the region ${ }^{2}$.

\section{CONCLUSIONS}

The aim of our research was the analysis of government bond spreads in the CEE countries. Using an econometric model based on the work of Beirne - Fratzscher (2013), the determinants of sovereign risk were assessed in three different periods: before the crisis (January 2001-September 2008), during the global financial crisis (October 2008-March 2010), and during the European debt crisis (April 2010-July 2014). The presented methodology enabled the examination of contagion-effects separately in each phase of the crisis.

2 The results of these robustness tests are available from the author upon request. 
The results of the empirical analysis confirm the significant relationship between sovereign risk and fiscal variables, economic output growth, and shortterm interest rates. The results also support the hypothesis that the impact of macroeconomic fundamentals changed during the crises. Financial markets became more sensitive to the fundamental variables during the global financial crisis, especially to output growth, which signals wake-up call contagion. Investors strongly distinguished countries based on macroeconomic fundamentals, and did not price sovereign risk based on the regional level of government bond yields. This finding suggests that the pricing of sovereign risk in the CEE region changed in a similar way as in the euro zone periphery countries. A key contribution of the paper to the literature is the separate analysis of sovereign risk during the European debt crisis. The results suggest that investors returned to the pre-crisis assessment of risk; however, the role of regional risk increased, which may signal regional contagion.

The analysis also showed that sovereign credit ratings have a significant impact on government bond yields throughout the whole period. The results suggest that investors price government bonds yields to a large extent based on credit ratings. However, the results do not show a significant impact of fiscal rules on spreads in the CEE countries.

The analysis also provides evidence on the significant role of exchange rate volatility on sovereign risk. The analysis supports that free-floating exchange rate regimes are beneficial during volatile periods. These findings are in line with the empirical works of other authors concerning advanced and emerging economies.

\section{REFERENCES}

Alexopoulou, I. - Bunda, I. - Ferrando, A. (2010): Determinants of Government Bond Spreads in New EU Countries. Eastern European Economics, 48(5): 5-37.

Antonakakis, N. - Vergos, K. (2013): Sovereign Bond Yield Spillovers in the Euro Zone during the Financial and Debt Crisis. Journal of International Financial Markets, Institutions and Money, 26: 258-272.

Ardagna S. - Caselli, F. - Lane T. (2007): Fiscal Discipline and the Cost of Public Debt Service: Some Estimates for OECD Countries. The BE Journal of Macroeconomics, 7(1): 1-33.

Attinasi, M. - Checherita-Westphal, C. - Nickel, C. (2009): What Explains the Surge in Euro Area Sovereign Spreads during the Financial Crisis of 2007-09? Working Paper, No. 1131, European Central Bank. Available at: http://papers.ssrn.com/sol3/Papers.cfm?abstract_id=1520351

Baldacci, E. - Kumar, M. (2010): Fiscal Deficits, Public Debt, and Sovereign Bond Yields. Working Paper, No. 184, IMF. Available at: http://papers.ssrn.com/sol3/papers.cfm?abstract_ id $=1669865$

Barrios, S. - Iversen, P. - Lewandowska, M. - Setzer, R. (2009): Determinants of Intra-Euro Area Government Bond Spreads during the Financial Crisis. European Economy-Economic Paper, 
No. 388. Available at: http://ec.europa.eu/economy_finance/publications/publication 16255 en.pdf

Beirne, J. - Fratzscher, M. (2013): The Pricing of Sovereign Risk and Contagion during the European Sovereign Debt Crisis. Journal of International Money and Finance, 34: 60-82.

Cantor, R. - Packer, F. (1996): Determinants and Impact of Sovereign Credit Ratings. Economic Policy Review, 2(2): 37-54.

Canuto, O. - Dos Santos, P. - de Sá Porto, P. (2004): Macroeconomics and Sovereign Risk Ratings. World Bank. Available at: http://siteresources.worldbank.org/EXTPREMNET/Resources /ratingsUSP.pdf

Cavallo, E. - Powell, A. - Rigobon, R. (2013): Do Credit Rating Agencies Add Value? Evidence from the Sovereign Rating Business. International Journal of Finance \& Economics, 18(3): 240-265.

Claeys, P. - Vašíček, B. (2014): Measuring Bilateral Spillover and Testing Contagion on Sovereign Bond Markets in Europe. Journal of Banking \& Finance, 46(C): 151-165.

Claeys, G. - Darvas, Zs. - Leandro, A. (2016): A Proposal to Revive the European Fiscal Framework. Bruegel Policy Contribution. Available at: http://bruegel.org/wp-content/uploads/2016/03/ pc_2016_07.pdf

Darvas, Zs. (2010): The Impact of the Crisis on Budget Policy in Central and Eastern Europe. OECD Journal on Budgeting, 10(1): 1-42.

Ebner, A. (2009): An empirical analysis on the determinants of CEE government bond spreads. Emerging Markets Review 10(2): 97-121.

Elmendorf, D. - Mankiw, N. (1999): Government Debt. Working Paper, No. 6470, NBER. Available at: http://www.nber.org/papers/w6470.pdf

Gadanecz, B. - Miyajima, K. - Shu, C. (2014): Exchange Rate Risk and Local Currency Sovereign Bond Yields in Emerging Markets. Working Paper, No. 474, BIS. Available at: http://www.bis. org/publ/work474.htm

Giday, A. (2013): Indebtedness in Central and Eastern Europe - Eight years of New EU Members. Public Finance Quarterly, 58(3): 271-292.

Giordano, R. - Pericoli, M.- Tommasino, P. (2013): Pure or Wake-up-Call Contagion? Another Look at the EMU Sovereign Debt Crisis. International Finance, 16(2): 131-160.

Gruber, J. - Kamin, S. (2010): Fiscal Positions and Government Bond Yields in OECD Countries. International Finance Discussion Papers, No. 1011. Available at: http://www.federalreserve. gov/pubs/ifdp/2010/1011/ifdp1011.pdf

Gómez-Puig, M. - Sosvilla-Rivero, S. - del Carmen Ramos-Herrera, M. (2014): An Update on EMU Sovereign Yield Spread Drivers in Times of Crisis: A Panel Data Analysis. The North American Journal of Economics and Finance, 30: 133-153.

Gómez-Puig, M. - Sosvilla-Rivero, S. (2014): Causality and Contagion in EMU Sovereign Debt Markets. International Review of Economics \& Finance, 33: 12-27.

Iara, A. - Wolff, G. B. (2014): Rules and Risk in the Euro Area. European Journal of Political Economy, 34(C): 222-236.

Jahjah, S. - Wei, B. - Zhanwei Yue, V. (2012): Exchange Rate Policy and Sovereign Bond Spreads in Developing Countries. International Finance Discussion Papers, No. 1049. Available at: http://www.federalreserve.gov/pubs/ifdp/2012/1049/ifdp1049.pdf

Jaramillo, L. - Tejada, M. (2011): Sovereign Credit Ratings and Spreads in Emerging Markets: Does Investment Grade Matter? Working Paper, No. 44, IMF. Available at: http://www10.iadb. org/intal/intalcdi/PE/2011/07826.pdf 
Jaramillo, L. - Weber, A. (2012): Bond Yields in Emerging Economies: It Matters What State You Are in. Working Paper, No. 198, IMF. Available at: http://papers.ssrn.com/sol3/papers. cfm?abstract id $=1780802$

Kattel, R. (2010): Financial and Economic Crisis in Eastern Europe. Journal of Post Keynesian Economics, 33(1): 41-60.

Lane, P. (2012): The European Sovereign Debt Crisis. The Journal of Economic Perspectives, 26(3): 49-67.

Laubach, T. (2009): New Evidence on the Interest Rate Effects of Budget Deficits and Debt. Journal of the European Economic Association, 7(4): 858-885.

Leschinski, C. - Bertram, P. (2013): Contagion Dynamics in EMU Government Bond Spreads. Hannover Economic Papers (HEP), available at:

http://diskussionspapiere.wiwi.uni-hannover.de/pdf_bib/dp-515.pdf

Ludwig, A. (2014): A Unified Approach to Investigate Pure and Wake-Up-Call Contagion: Evidence from the Eurozone's First Financial Crisis. Journal of International Money and Finance, 48: $125-146$.

Miyajima, K. - Mohanty, M. - Chan, T. (2015): Emerging Market Local Currency Bonds: Diversification and Stability. Emerging Markets Review, 22(C): 126-139.

Mundell, R. (1963): Capital Mobility and Stabilization Policy under Fixed and Flexible Exchange Rates. Canadian Journal of Economics and Political Science/Revue canadienne de economiques et science politique, 29(4): 475-485.

Poghosyan, T. (2014): Long-run and Short-run Determinants of Sovereign Bond Yields in Advanced Economies. Economic Systems, 38(1): 100-114.

Staehr, K. (2010): The Global Financial Crisis and Public Finances in the New EU Countries from Central and Eastern Europe. Public Finance and Management, 10(4): 671-712.

Suh, S. (2015): Measuring Sovereign Risk Contagion in the Eurozone. International Review of Economics \& Finance, 35: 45-65.

Vamvakidis, A. (2009): Convergence in Emerging Europe: Sustainability and Vulnerabilities. Eastern European Economics, 47(3): 5-27.

Von Hagen, J. - Schuknecht, L. - Wolswijk, G. (2011): Government Bond Risk Premiums in the EU Revisited: The Impact of the Financial Crisis. European Journal of Political Economy, 27(1): 36-43. 


\section{APPENDIX}

Table A1. The Hausman test

\begin{tabular}{|c|c|c|c|c|}
\hline Variable & $\begin{array}{l}\text { (b) } \\
\text { Fixed }\end{array}$ & $\begin{array}{c}\text { (B) } \\
\text { Random }\end{array}$ & $\begin{array}{c}\text { (b-B) } \\
\text { Difference }\end{array}$ & $\begin{array}{c}\text { sqrt(diag(V_b- } \\
\text { V_B) S.E. }\end{array}$ \\
\hline growth & -.0571084 & -.097531 & .0404226 & \\
\hline def stock $\sim p$ & -.0454706 & .0214987 & -.0669694 & \\
\hline bop gp & .0704591 & .0126905 & .0577686 & \\
\hline debt & .0393094 & .0012077 & .0381017 & .0057227 \\
\hline vix quart & .0064485 & -.0175091 & .0239576 & \\
\hline mmr quart & .3006235 & .3584063 & -.0577828 & .0196586 \\
\hline spread qua $\sim$ n & -.0117437 & -.1232158 & .1114721 & \\
\hline dep_quart & -.0111333 & .0641079 & -.0752412 & \\
\hline cv_quart & 8.785723 & 11.69063 & -2.90491 & \\
\hline growth_cr & -.3121522 & -.3453255 & .0331732 & \\
\hline def sto $\sim \mathrm{p}$ cr & -.1560088 & -.2578427 & .1018339 & \\
\hline bop gp cr & -.0935489 & -.0705319 & -.023017 & \\
\hline debt_cr & .0261904 & .0338826 & -.0076923 & \\
\hline vix_quart_cr & .0223718 & .0232894 & -.0009176 & \\
\hline mmr_quart_cr & -.1498743 & -.0029968 & -.1468775 & \\
\hline spread qua $\sim \mathrm{r}$ & -.5418299 & -.6442251 & .1023952 & \\
\hline cv_quart_cr & -46.3515 & -81.37078 & 35.01919 & \\
\hline dep_quart_cr & .0307543 & -.0047472 & .0355015 & \\
\hline growth_fc & -.1060074 & .1331489 & -.2391563 & \\
\hline def sto $\sim p$ fc & .0198112 & -.0463042 & .0661154 & \\
\hline bop gp fc & .0394344 & .213595 & -.1741606 & \\
\hline debt_fc & .0034275 & -.0140768 & .0175043 & \\
\hline vix_quart_fc & .0351873 & .0407224 & -.0055351 & \\
\hline mmr_quart_fc & .0739657 & .4134437 & -.339478 & \\
\hline spread_qua $\sim$ c & .2235 & .6174698 & -.3939699 & \\
\hline \multicolumn{5}{|c|}{$\begin{array}{l}\mathrm{b}=\text { consistent under Ho and Ha; obtained from xtreg } \\
\mathrm{B}=\text { inconsistent under Ha, efficient under Ho; obtained from xtreg } \\
\text { Test: Ho: difference in coefficients not systematic } \\
\left.\text { chi2(12)=(b-B)'[(V_b-V_B })^{\wedge}(-1)\right](\mathrm{b}-\mathrm{B}) \\
=330.97\end{array}$} \\
\hline \multicolumn{5}{|c|}{$\begin{array}{l}\text { Prob }>\text { chi2 } \mathbf{~}=\mathbf{0 . 0 0 0 0} \\
(V b-V B \text { is not positive definite })\end{array}$} \\
\hline
\end{tabular}


Table A2. The results of the VIF test

\begin{tabular}{llc}
\hline Variable & VIF & 1/VIF \\
\hline qratingA & 4.79 & 0.208554 \\
qratingAplus & 4.35 & 0.229997 \\
qrat $\sim$ BBBplus & 3.79 & 0.263745 \\
qratingBBB & 3.40 & 0.294489 \\
qratingAA & 3.15 & 0.317343 \\
spread qua $\sim \mathrm{n}$ & 3.06 & 0.326541 \\
growth & 2.95 & 0.338780 \\
mmr quart & 2.70 & 0.370340 \\
bop gp & 2.60 & 0.384654 \\
qra BBBminus & 2.60 & 0.384954 \\
qratingAmi $\sim \mathrm{s}$ & 2.36 & 0.423141 \\
cv_quart & 2.09 & 0.478933 \\
vix_quart & 2.03 & 0.493066 \\
debt & 1.89 & 0.528257 \\
def stock $\sim \mathrm{p}$ & 1.71 & 0.585855 \\
fri_quart & 1.47 & 0.681940 \\
dep_quart & 1.26 & 0.791234 \\
qratingBBp $\sim \mathrm{s}$ & 1.15 & 0.872704 \\
\hline
\end{tabular}

Mean VIF 2.63 